\title{
An Exercise Prescription for COVID-19 Pandemic
}

\author{
Zait Burak Aktug', Nazlım Aktug Demir ${ }^{2}$
}

\begin{abstract}
SUMMARY
COVID-19 is an alarming public health concern worldwide. COVID-19 is highly contagious and has no approved treatment or vaccine yet. Therefore, the best strategy is prevention. Studies have shown that a healthy lifestyle, regular exercise, balanced eating, and quality sleep are the key elements for protection from this disease. We are going through a distressful period as a nation and as the human race in general. We need to manage this period in the best way possible in physiological and psychological terms. Physical activity is one of the major steps in managing this period in a healthy way. Individuals should be provided information about exercise so that they can perform correct physical activities within their means. This article presents an exercise prescription that can be followed in the days of the COVID-19 pandemic.
\end{abstract}

KEYWORDS: COVID-19, Exercise prescription, Health.

doi: https://doi.org/10.12669/pjms.36.7.2929

How to cite this:

Aktug ZB, Demir NA. An Exercise Prescription for COVID-19 Pandemic. Pak J Med Sci. 2020;36(7):1732-1736. doi: https://doi.org/10.12669/pjms.36.7.2929

This is an Open Access article distributed under the terms of the Creative Commons Attribution License (http://creativecommons.org/licenses/by/3.0), which permits unrestricted use, distribution, and reproduction in any medium, provided the original work is properly cited.

\section{INTRODUCTION}

COVID-19 is an alarming public health concern worldwide. The clinical findings of COVID-19 infection exhibit a broad spectrum of conditions ranging from asymptomatic disease or mild upper respiratory tract infection to severe viral pneumonia involving respiratory failure that can result in death. ${ }^{1,2}$

Coronaviruses, in which SARS-CoV-2 is a member, are a large virus family at times causing

1. Dr. Zait Burak Aktuğ

Niğde Ömer Halisdemir University,

Sports Science Faculty,

Nigde, Turkey.

2. Dr. Nazlım Aktuğ Demir

Selcuk University, Faculty of Medicine,

Department of Clinical Microbiology and Infectious Diseases,

Konya, Turkey.

Correspondence:

Dr. Zait Burak Aktuğ,

Associate Professor,

Niğde Ömer Halisdemir University,

Sports Science Faculty,

Niğde, Turkey.

Email: zaitburak@gmail.com

* Received for Publication:

* Revision Revised:

* Revision Accepted:

May 19, 2020

August 24, 2020

August 30, 2020 only self-limiting mild infections widely seen in the community such as common cold and at other times leading to more serious infections such as Middle East Respiratory Syndrome (MERS) and Severe Acute Respiratory Syndrome (SARS). SARS-CoV made its appearance in 2003 as a previously unknown virus and caused deaths of a large number of people. MERS-CoV was defined first approximately 10 years later in September 2012 in Saudi Arabia. Finally, in December 2019, the SARS-CoV-2 agent was defined in the pneumonia outbreak that took place in China with the city of Wuhan as the centre. This new disease was named COVID-19.,4 COVID-19 is highly contagious and has no approved treatment or vaccine yet. Therefore, the best strategy is protection. Studies have shown that a healthy lifestyle, regular exercise, balanced eating, and quality sleep are the key elements for protection from this disease. ${ }^{5,6}$

Isolation is important to control the disease, but it also involves many unfavourable physiological and psychological effects. ${ }^{7}$ Changing lifestyles and behaviours in this period may result in inadequate physical activity and movement, ${ }^{8,9}$ which will pave the way for diabetes, hypertension, cardiovascular 
diseases, respiratory diseases, and mental disorders., ${ }^{910}$ For individuals to go through this process in a healthy manner, they will need to adapt to this kind of living. It is essential to remain active and maintain an exercise routine during quarantine periods to protect mental and physical health. ${ }^{11}$

\section{Exercise and Health:}

The World Health Organization has defined health as a state of complete physical, mental, and social well-being and not merely the absence of infirmity or disease. Health is an inseparable whole with all its physical and mental dimensions and affects each other. ${ }^{12}$ Uncertainty about the time it will take to end the COVID-19 pandemic, fear and anxiety arousing news in the social media, quarantine processes, etc. lead to a variety of problems including stress, anxiety, depression, and sleep disorders. ${ }^{13,14}$

Exercises are planned and repetitive movements structured to protect, improve, and develop physical health. Regular exercise have major contributions to the prevention and treatment of some health problems including diabetes, obesity, hyperlipidemia, cardiovascular diseases, some cancer types, and osteoporosis. ${ }^{15-21}$ Exercise also has other positive effects such as reducing anxiety, stress and depression, sustaining mental health, and achieving psychological well-being. ${ }^{22,23}$ Exercise is known to enhance self-perception, promote social functioning, and improve night sleep by limiting daytime sleep. ${ }^{22,24-26}$

The effects of exercise on mental health occur in two ways: The first one is associated with the increase in synaptic transmission of monoamines induced by physical activity, which resembles the mechanism of action of antidepressant drugs. ${ }^{27,28}$ The second occurs when physical activity causes the secretion of endorphin (primarily betaendorphin), which suppresses the central nervous system creating a state of calmness and mental relaxation. ${ }^{29,30}$

Studies investigating the effects of exercise on mental health in the literature use various exercise types with varying intensities, frequencies, and durations. There are different opinions as to which types of exercise are more effective on mental health..$^{31-34}$

Two points should be considered when deciding on the exercises to be carried out during the COVID-19 pandemic. It is important to choose the exercises that will simultaneously strengthen both our mental health and immune system, the latter being our core protector in this time of disease.
Many people are unwilling to engage in physical activity due to working conditions, children, spouse, insufficient time, physical constraints, boring nature of some exercises, and sedentary lifestyle. ${ }^{35}$ The important thing here is to choose exercises which we would enjoy doing and will keep us occupied with the activity. Most of the patients with depression have stated that they enjoy moderate-intensity exercises (maximum heart rate $60-80 \%$ ) rather than high-intensity exercises. $^{36}$ In attempts to use high-intensity exercises as a start, approximately half of the patients choose to not continue exercise. ${ }^{37}$ In such cases, starting with low-intensity aerobic exercises is recommended to ensure the continuation of the exercise because they are found more enjoyable. ${ }^{35}$ Many studies have shown that aerobic exercises have no negative effect on mental diseases; on the contrary, they are effective in the prevention and treatment of mental diseases. . $^{31,32}$ High-intensity exercises are known to exert a suppressive effect on the immune system, whereas low and moderate-intensity aerobic exercises improve the immune system. Aerobic and low-intensity resistance training are argued to be more effective than aerobic exercises alone ${ }^{38,39}$ and for this reason, strength exercises alongside aerobic exercises are recommended during the COVID-19 pandemic. Since frequent workouts have been found more effective in reducing depression symptoms, ${ }^{40}$ efforts should be made to encourage patients to do workouts as often as possible in this period. Based on the above information, we think that practicing the exercise programs given below will yield positive results in this period.

\section{COVID-19 PROCESS AND EXERCISE PRESCRIPTION}

* Those newly starting exercise should practice these exercises at least three days a week and those regularly exercise at least five days a week.

* Resistance exercise days should be scheduled to be between aerobic exercise days.

* Care should be taken about the intensity of exercises; excessively tiring and anaerobic workouts should be avoided.

* Those newly starting exercise should increase first the frequency, then the duration, and then the intensity of the exercise in time.

Table-I shows the intensity and duration of the exercise are between certain intervals. If you increase the intensity, you should decrease the 
Table-I: Exercise program for those who can train in the open air and have the equipment for strength exercises at home.

\begin{tabular}{|c|c|c|c|c|c|}
\hline & & Exercise type & $\begin{array}{l}\text { Exercise } \\
\text { Duration }\end{array}$ & $\begin{array}{l}\text { Exercise } \\
\text { Frequency }\end{array}$ & $\begin{array}{l}\text { Exercise } \\
\text { Intensity }\end{array}$ \\
\hline \multirow{3}{*}{$\begin{array}{l}\text { Aerobic } \\
\text { Exercises }\end{array}$} & $\begin{array}{l}\text { Individuals who } \\
\text { will newly start } \\
\text { exercise }\end{array}$ & $\begin{array}{l}\text { Walking (90-100 steps/ } \\
\text { minutes.) } \\
\text { Cycling (12-14 km/hour) }\end{array}$ & 20-35 minutes & 2 days/week & $\begin{array}{l}\text { MHRR } \\
30-55 \%\end{array}$ \\
\hline & $\begin{array}{l}\text { Regularly } \\
\text { exercise } \\
\text { individuals }\end{array}$ & $\begin{array}{l}\text { Walking (>120 steps/minutes.) } \\
\text { Cycling ( } 15-18 \mathrm{~km} / \text { hour) } \\
\text { Jogging or running (At least } 40 \\
\text { pulses more than resting HR) }\end{array}$ & $35-60$ minutes & 3-4 days/week & $\begin{array}{l}\text { MHRR } \\
60-80 \%\end{array}$ \\
\hline & & Number of Sets & $\begin{array}{l}\text { Number of } \\
\text { Repetitions }\end{array}$ & $\begin{array}{l}\text { Exercise } \\
\text { Frequency }\end{array}$ & $\begin{array}{l}\text { Exercise } \\
\text { Intensity }\end{array}$ \\
\hline \multirow{2}{*}{$\begin{array}{l}\text { Resistance } \\
\text { Exercises }\end{array}$} & $\begin{array}{l}\text { Individuals who } \\
\text { will exercise for } \\
\text { the first time }\end{array}$ & $\begin{array}{l}\text { For each movement } \\
1-2 \text { sets }\end{array}$ & $8-12$ & 1-2 days/week & $\begin{array}{l}1 \mathrm{RM} \\
30-50 \%\end{array}$ \\
\hline & $\begin{array}{l}\text { Regularly } \\
\text { exercise } \\
\text { individuals }\end{array}$ & $\begin{array}{l}\text { For each movement } \\
2-3 \text { sets }\end{array}$ & $8-12$ & 2-3 days/week & $\begin{array}{l}1 \mathrm{RM} \\
50-70 \%\end{array}$ \\
\hline
\end{tabular}

MHRR: Maximal heart rate reserve RM: Maximal repetition HR: Heart rate.

duration. This means that intensity and duration should be inversely proportional.

* Resistance exercises should be composed of at least five movements that work out different muscle groups. These movements should involve both the lower and upper extremities. The movements should address to large and small muscle groups.

1. The Sample program, $1^{\text {st }}$ move: squat; $2^{\text {nd }}$ move: shoulder press; $3^{\text {rd }}$ move: sit-up; $4^{\text {th }}$ move: leg curl; $5^{\text {th }}$ move: triceps extension; $6^{\text {th }}$ move: lat pulldown.

2. The Sample program, $1^{\text {st }}$ move: leg extension; $2^{\text {nd }}$ move: barbell curl; $3^{\text {rd }}$ move: chin up; $4^{\text {th }}$ move: leg curl; $5^{\text {th }}$ move: bench press; $6^{\text {th }}$ move: shoulder press.

3. The Sample program, $1^{\text {st }}$ move: Romanian deadlift; $2^{\text {nd }}$ move: $\mathrm{z}$ bar barbell curl; $3^{\text {rd }}$ move: dumbell fly; $4^{\text {th }}$ move: hack squat; $5^{\text {th }}$ move: side lateral raise; $6^{\text {th }}$ move: one arm dumbell row

4. The Sample program, $1^{\text {st }}$ move: leg press; $2^{\text {nd }}$ move: cable push down; $3^{\text {rd }}$ move: sit-up; $4^{\text {th }}$ move: leg curl; $5^{\text {th }}$ move: barbell incline press; $6^{\text {th }}$ move: hyperextension.

* Each of these sample programs is composed of 6 movements that work out a different muscle group. The movements are designed to work out both the lower and upper extremities.

* Exercise types are shown in letters. One of the exercise types shown for aerobic exercises will be chosen.

* Muscle groups in resistance exercises are shown in letters. One movement for each muscle group will be chosen; six movements in total will be included.

Table-II: Exercise program for those who have to train at home.

\begin{tabular}{llllll}
\hline & & Exercise Type & Exercise Duration & Exercise Set & Exercise Frequency \\
\hline \multirow{2}{*}{$\begin{array}{l}\text { Aerobic } \\
\text { Exercises }\end{array}$} & $\begin{array}{l}\text { Individuals newly starting } \\
\text { exercise }\end{array}$ & a,b,e & $10-20$ minutes. & $1-2$ & 2 days/week \\
& Regularly exercise individuals & $\mathrm{c}, \mathrm{d}, \mathrm{e}$ & $15-30$ minutes. & $2-3$ & 3-4 days/week \\
\hline \multirow{2}{*}{$\begin{array}{l}\text { Resistance } \\
\text { Exercises }\end{array}$} & $\begin{array}{l}\text { Inpe } \\
\text { Individuals newly starting }\end{array}$ & $\begin{array}{l}\text { Number of } \\
\text { Repetition }\end{array}$ & $\begin{array}{l}\text { Exercise } \\
\text { Set }\end{array}$ & Exercise Frequency \\
\hline
\end{tabular}


* Care should be taken about the intensity of exercises; excessively tiring and anaerobic workouts should be avoided.

* Those newly starting exercise should increase first the frequency, then the duration, and then the intensity of the exercise in time.

* Resistance exercise days should be scheduled to be between aerobic exercise days.

* The intensity and duration of the exercise should be inversely proportional.

Aerobic Exercises:

* (a) Stepping up and down on a 30-40 cm raised platform with a pace $60-70$ steps/minutes.

* (b) Walking where you are with a pace 70-90 steps/minutes. (The feet should be raised a little higher than in normal walking position)

* (c) Stepping up and down on a 30-40 cm raised platform with a pace 90-110 steps/minutes.

* (d) Walking where you are with a pace $>100$ 120 steps/minutes. (The feet should be raised a little higher than in normal walking position)

* (e) Zumba, oriental, dance

Resistance Exercises:

* Resistance bands were chosen when preparing the program as they are low-cost and readily available items.

* New beginners should use moderate-level resistance bands (yellow or red / moderatelevel).

* Regularly exercise individuals should use highlevel resistance bands (blue or black / difficultlevel).

\section{Resistance Exercise Movements Using Resistance} Bands:

* (a) Arm exercises: Biceps curl, one arm upright; triceps extension

* (b) Shoulder exercises: Lateral rise; upright row; front rise; shoulder diagonal flexion

* (c) Back exercises: Lat pulldown back; scapular retraction; band seated row

* (d) Chest exercises: Chest fly; chest press; pushup

* (e) Leg exercises: Lunge; leg press; hip adduction; hip abduction; squat

* (f) Abdominutesal exercises: Abdominutesal crunch; flutter kick; air bike crunches; knees up crunch

\section{CONCLUSION}

We are going through a distressful period as a nation and as the human race in general. We need to manage this period in the best way possible in physiological and psychological terms. Physical activity is one of the major steps in managing this period in a healthy way. Individuals should be provided information about exercise so that they can perform correct physical activities within their means. This article presents an exercise prescription that can be followed in the days of the COVID-19 pandemic.

Conflicts of Interest: The authors declare that they have no conflict of interests.

\section{Grant Support E Financial Disclosures: None. \\ REFERENCES}

1. Perlman S. Another decade, another coronavirus. N Engl J Med. 2020;382:760-762. doi: 10.1056/NEJMe2001126

2. Tang $X, W u ~ C, L i ~ X$, Song $Y, Y a o X, W u$ X, et al. On the origin and continuing evolution of SARS-CoV-2. Natl Sci Rev. 2020;nwaa036. doi: 10.1093/nsr/nwaa036

3. World Health Organization. Novel coronavirus (2019-nCoV) technical guidance, https://www.who.int/emergencies/ diseases/novel-coronavirus-2019/technical-guidance; 2020 [Accessed 05.May.2020].

4. Centers for Disease Control and Prevention. Interim clinical guidance for management of patients with confirmed 2019 novel Coronavirus (2019-nCoV) infection, https:/ / www.cdc.gov/ coronavirus/2019-ncov/hcp/ clinical-guidance-management patients. html; 2020 [Accessed 05.May.2020].

5. Kim SW, Su KP. Using psychoneuro immunity against Covid-19. Brain Behav Immun. 2020;87:4-5. doi: 10.1016/j. bbi.2020.03.025

6. Aman F, Masood S. How nutrition can help to fight against COVID-19 pandemic. Pak J Med Sci. 2020;36(COVID19-S4):121-123. doi: 10.12669/pjms.36. COVID19-S4.2776

7. Brooks SK, Webster RK, Smith LE, Woodland L, Wessely S, Greenberg N, et al. The psychological impact of quarantine and how to reduce it: rapid review of the evidence. Lancet. 2020;395:912-920. doi: 10.1016/S0140-6736(20)30460-8

8. Lavie CJ, Ozemek C, Carbone S, Katzmarzyk PT, Blair SN. Sedentary behavior, exercise, and cardiovascular health. Circ Res. 2019;124(5):799-815. doi: 10.1161/ CIRCRESAHA.118.312669

9. Ozemek C, Lavie CJ, Rognmo O. Global physical activity levels: need for intervention. Prog Cardiovasc Dis. 2019;62(2):102-107. doi: 10.1016/j.pcad.2019.02.004

10. Ozemek C, Laddu DR, Lavie CJ, Claeys H, Kaminutessky LA, Ross R, et al. An update on the role of cardiorespiratory fitness, structured exercise and lifestyle physical activity in preventing cardiovascular disease and health risk. Prog Cardiovasc Dis. 2018;61(5-6):484-490. doi: 10.1016/j. pcad.2018.11.005

11. Wu W, Zhang Y, Wang P, Zhang L, Wang G, Lei G, et al. Psychological stress of medical staffs during outbreak of COVID-19 and adjustment strategy. J Med Virol. 2020. doi: $10.1002 / j m v .25914$

12. WHO Constitution. World Health Organization, Geneva, 1948.

13. Altena E, Baglioni C, Espie CA, Ellis J, Gavriloff D, Holzinger B, et al. Dealing with sleep problems during home confinement due to the COVID-19 outbreak: Practical recommendations from a task force of the European CBT-I Academy. J Sleep Res. 2020;4:e13052. doi: 10.1111/jsr.13052. 
14. Hashmi AM, Saleem HA. New Horizons: COVID-19 and the Burden of Neuropsychiatric Illness in Pakistan. Pak J Med Sci. 2020;36(COVID19-S4):COVID19-S95-S98. doi: 10.12669/ pjms.36.COVID19-S4.2792

15. Sui X, Sarzynski MA, Lee DC, Kokkinos PF. Impact of changes in cardiorespiratory fitness on hypertension, dyslipidemia and survival: An overview of the epidemiological evidence. Prog Cardiovasc Dis. 2017;60(1):56-66. doi: 10.1016/j.pcad.2017.02.006

16. Harber MP, Kaminutessky LA, Arena R, Blair SN, Franklin BA, Myers J, et al. Impact of cardiorespiratory fitness on all-cause and disease-specific mortality: advances since 2009. Prog Cardiovasc Dis. 2017;60(1):11-20. doi: 10.1016/j. pcad.2017.03.001

17. Nauman J, Tauschek LC, Kaminutessky LA, Nes BM, Wisloff U. Global fitness levels: findings from a web-based surveillance report. Prog Cardiovasc Dis. 2017;60(1):78-88. doi: 10.1016/j.pcad.2017.01.009

18. Huai P, Xun H, Reilly KH, Wang Y, Ma W, Xi B. Physical activity and risk of hypertension: A meta-analysis of prospective cohort studies. Hypertension. 2013;62(6):10211026. doi: 10.1161/HYPERTENSIONAHA.113.01965

19. Howe TE, Shea B, Dawson LJ, Downie F, Murray A, Ross $\mathrm{C}$, et al. Exercise for preventing and treating osteoporosis in postmenopausal women. Cochrane Database Syst Rev. 2011;6(7):CD000333. doi: 10.1002/14651858.CD000333. pub2.

20. Mammen G, Faulkner G. Physical activity and the prevention of depression: a systematic review of prospective studies. Am J Prev Med. 2013;45(5):649-657. doi: 10.1016/j. amepre.2013.08.001

21. Lee IM. Physical activity and cancer prevention-data from epidemiologicstudies.MedSciSportsExerc. 2003;35(11):18231827. doi: 10.1249/01.MSS.0000093620.27893.23

22. Lok S, Lok N. Efficiency of physical exercise programs on chronic psychiatric patients: A systematic review. Curr Approac Psychiat. 2016;8(4):354-366. doi: 10.18863/ pgy. 253440

23. Wipfli BM, Rethorst CD, Landers DM. The anxiolytic effects of exercise: a meta-analysis of randomized trials and doseresponse analysis. J Sport Exerc Psychol. 2008;30(4):392-410. doi: 10.1123 /jsep.30.4.392

24. Fariz B. Psikiyatrik hastalıklar ve egzersiz. Turk J Sports Med. 2015;50:131-138. (Turkish)

25. Brunes A, Gudmundsdottir SL, Augestad LB. Genderspecific associations between leisure-time physical activity and symptoms of anxiety: the HUNT study. Soc Psychiatry Psychiatr Epidemiol. 2015;50(3):419-427. doi: 10.1007/ s00127-014-0915-z

26. King AC, Oman RF, Brassington GS, Bliwise DL, Haskell WL. Moderate-intensity exercise and self-rated quality of sleep in older adults. A randomized controlled trial. JAMA. 1997;277(1):32-37. doi:10.1001/jama.277.1.32

27. Dunn AL, Dishman RK. Exercise and the neurobiology of depression. Exerc Sport Sci Rev. 1991;19:41-98.

28. Nicoloff G, Schwenk TL. Using exercise to ward off depression. Phys Sportsmed. 1995;23(9):44-58. doi: 10.1080/00913847.1995.11947838

29. Ransford CP. A role for aminuteses in the antidepressant effect of exercise: a review. Med SciSports Exerc. 1982;14(1):110. doi: 10.1249/00005768-198201000-00001
30. Blanchard CM, Rodgers WM, Spence JC, Courneya KS. Feeling state responses to acute exercise of high and low intensity. J Sci Med Sport. 2001;4(1):30-38. doi: 10.1016/ s1440-2440(01)80005-0

31. Nabkasorn C, Miyai N, Sootmongkol A, Junprasert $S$, Yamamoto H, Arita M, et al. Effects of physical exercise on depression, neuroendokrine stress hormones and physiological fitness in adolescent females with depressive symptoms. Eur J Public Helath. 2006;16(2):179-184. doi: 10.1093/eurpub/cki159

32. Loh SY, Abdullah A, Bakar AKA, Thambu M, Jaafar NRN. Structured walking and chronic institutionalized schizophrenia inmates: a pilot RCT study on quality of life. Glob J Health Sci. 2016;8(1):238-248. doi:10.5539/gjhs. v8n1p238

33. Teixeira RB, Marins JCB, de Sa-Junior AR, de Carvalho CJ, da Silva Moura TA, Lade CG, et al. Improved cognitive, affective and anxiety measures in patients with chronic systemic disorders following structured physical activity. Diab Vasc Dis Res. 2015;12(6):445-454. doi: 10.1177/1479164115602651

34. Chalder M, Wiles NJ, Campbell J, Hollinghurst SP. Searle A, Haase AM, et al. A pragmatic randomised controlled trial to evaluate the cost-effectiveness of a physical activity intervention as a treatment for depression: the treating depression with physical activity (TREAD) trial. Health Technol Assess. 2012;16(10). doi: 10.3310/hta16100

35. Çelebi MM. Spor hekimliginin ruh sagligini koruma ve iyilestirmedeki rolu: multidisipliner yaklaşı fiziksel degerlendirme egzersiz receteler. Turkiye Klinikleri J Sports Med-Special Topics. 2016;2(2):59-64. (Turkish)

36. Berger BG, Owen DR. Relation of low and moderate intensity exercise with acute mood change in college joggers. Percept Mot Skills. 1998;87(2):611-621. doi: 10.2466/ pms.1998.87.2.611

37. Sallis JF, Haskell WL, Fortmann SP, Vranizan KM, Taylor $\mathrm{CB}$, Solomon DS. Predictors of adoption and maintenance of physical activity in a community sample. Prev Med. 1986;15(4):331-334. doi: 10.1016/0091-7435(86)90001-0

38. Cooney GM, Dwan K, Greig CA, Lawlor DA, Rimer J, Waugh FR, et al. Exercise for depression. Cochrane Database Syst Rev. 2013;9:CD004366. doi: 10.1002/14651858.CD004366. pub6

39. Rethorst CD, Wipfli BM, Landers DM. The antidepressive effects of exercise: a meta analysis of randomized trials. Sports Med. 2009;39(6):491-511. doi:10.2165/00007256200939060-00004.

40. Legrand F, Heuze JP. Antidepressant effects associated with different exercise conditions in participants with depression: a pilot study. J Sport Exerc Psychol. 2007;29(3):348-364. doi:10.1123/jsep.29.3.348

\section{Authors' Contribution:}

ZBA: Conceived, did manuscript writing and editing of manuscript

NAD: Did manuscript writing and final approval of manuscript, literature review. 